慶應義塾大学学術情報リポジトリ

Keio Associated Repository of Academic resouces

\begin{tabular}{|c|c|}
\hline Title & Oxygenated sterols as inhibitors of enzymatic conversion of dihydrolanosterol into cholesterol \\
\hline \multicolumn{2}{|l|}{ Sub Title } \\
\hline Author & $\begin{array}{l}\text { 佐藤, 良博(Sato, Yoshihiro) } \\
\text { 園田，上し子( Sonoda, Yoshiko) } \\
\text { 森崎, 益雄( Morisaki, Masuo) } \\
\text { 池川, 信夫( Ikekawa, Nobuo) }\end{array}$ \\
\hline Publisher & 共立薬科大学 \\
\hline Publication year & 1984 \\
\hline Jtitle & $\begin{array}{l}\text { 共立薬科大学研究年報 (The annual report of the Kyoritsu College of } \\
\text { Pharmacy). No.29 (1984. ) ,p.68- } 69\end{array}$ \\
\hline \multicolumn{2}{|l|}{ JaLC DOI } \\
\hline \multicolumn{2}{|l|}{ Abstract } \\
\hline Notes & 抄録 \\
\hline Genre & Technical Report \\
\hline URL & $\begin{array}{l}\text { https://koara.lib.keio.ac.jp/xoonips/modules/xoonips/detail.php?koara_id=AN00062898-0000002 } \\
\text { 9-0068 }\end{array}$ \\
\hline
\end{tabular}

慶應義塾大学学術情報リポジトリ(KOARA)に掲載されているコンテンツの著作権は、それぞれの著作者、学会または出版社/発行者に帰属し、その権利は著作権法によって 保護されています。引用にあたっては、著作権法を遵守してご利用ください。

The copyrights of content available on the KeiO Associated Repository of Academic resources (KOARA) belong to the respective authors, academic societies, or publishers/issuers, and these rights are protected by the Japanese Copyright Act. When quoting the content, please follow the Japanese copyright act. 
No. 29 (1984)

\title{
Oxygenated Sterols as Inhibitors of Enzymatic Conversion of Dihydrolanosterol into Cholesterol*
}

\author{
Yoshihiro Sato, Yoshiko Sonoda, Masuo MorisaKI** \\ and Nobuo IKEKAwA** \\ 佐藤良博, 園田よし子, 森崎益雄**, 池川信夫**
}

It has been established that certain oxygenated sterols, e.g. 25-hydroxycholesterol and 7-oxocholesterol are potent inhibitors of sterol synthesis and consequently are cytotoxic in various mammalian cells. One of the targets of this action of oxygenated sterols is 3-hydroxy-3-methylglutaryl-CoA (HMG-CoA) reductase, the rate-limiting enzyme in the sterol synthetic pathway which catalyzes the formation of mevalonic acid. This is consistent with our recent finding that oxygenated sterols are not toxic to the silkworm Bombyx mori, which lack de novo sterol biosynthesis. In addition to the inhibition of sterol synthesis, oxygenated sterols also affect human polymorphonuclear leucocyte chemotaxis, echinocyte formation of red blood cells, and platelet aggregation in plasma. These effects are perhaps related to the insertion of oxygenated sterols into plasma membranes and the consequent derangement of the membrane properties and function. Furthermore, oxygenated sterols reportedly possess angiotoxic properties and are suspected of being atherogenic.

In our continuing investigations of the biological effects of oxygenated sterols, we have now examined the influence of these compounds on enzymatic conversion of 24,25dihydrolanosterol into cholesterol. By the same method as described previously, [24,25${ }^{3} \mathrm{H}$ ]-24,25-dihydrolanosterol was incubated with the rat liver homogenate $S_{10}$ fraction in the presence of oxygenated sterol. The results are summarized in Table I. Essentially identical results were obtained on incubation with $\left[24-{ }^{3} \mathrm{H}\right]-l a n o s t e r o l$. It is clear that all the oxygenated sterols tested have a considerably potent inhibitory effect on cholesterol synthesis from dihydrolanosterol and lanosterol. $5 \alpha$-Cholest-8(14)-en-3 $\beta$ ol-15-one was found to be the most potent of the sterols examined. Schroepfer and his coworkers reported that this ketone caused slight (12-15\%) inhibition of the synthesis of digitonin-precipitable sterols from labelled acetate, but not from mevalonate, upon icubation with the $S_{10}$ fraction of rat liver, even though this compound is an inhibitor of sterol synthesis in cultured cells and a potent hypocholesterolemic agent in intact animals. Our present results appear to be at variance with that reported. The main differences in experimental conditions between the two studies were the sunstrate used (acetate or

* 本報告は Chem. Pharm. Bull., 32, 3305-3308（1984）に発表

** 東京工業大学 
No. 29 (1984)

Table I Cholesterol Biosynthesis during Incubation of the $\mathrm{S}_{10}$ Fraction of Rat Liver Homogenate with $\left[24,25^{-3} \mathrm{H}\right]-24,25$-Dihydrolanosterol in the Presence of Oxygenated Cholesterol Derivatives

\begin{tabular}{|c|c|c|c|}
\hline Compound & $\begin{array}{l}\text { 24,25-Dihydrolanosterol } \\
\text { fr. (\%6) }\end{array}$ & $\begin{array}{l}\text { Cholesterol } \\
\text { fr. (\%) }\end{array}$ & $\begin{array}{l}\text { Inhibition } \\
\quad(\%)\end{array}$ \\
\hline None (control) & 27.7 & 22.3 & - \\
\hline $5 \alpha$-Cholest-8(14)-en-3 $\beta$-ol-15-one & 58.2 & 8.1 & 64 \\
\hline 7-Oxocholesterol & 39.3 & 16.7 & 25 \\
\hline 24-Oxocholelterol & 44.1 & 13.2 & 41 \\
\hline (24S)-24,25-Epoxycholesterol & 53.1 & 10.3 & 54 \\
\hline (24R)-24,25-Epoxycholesterol & 44.2 & 15.4 & 31 \\
\hline (22S)-22-Hydroxycholesterol & 42.0 & 16.4 & 26 \\
\hline (22R)-22-Hydroxycholesterol & 44.9 & 15.1 & 32 \\
\hline
\end{tabular}

mevalonate $v s$. dihydrolanosterol), the concentration of the substrate and test compounds, and the method of preparation of the emulsions of the compounds.

In our previous paper concerning the effects of oxygenated lanosterol analogs, we demonstrated that 7-oxo-24,25-dihydrolanosterol was an extremely potent inhibitor of cholesterol synthesis from lanosterol. However, in the present experiment 7-oxocholesterol was found to be only marginally inhibitory. This is another indication of the importance of the steroid nucleus structure in eliciting the inhibitory activity, and is reminiscent of the reported differential effect of $14 \alpha$-ethyl-5 $\alpha$-cholest-7-ene-3 $\beta, 15 \alpha$-diol and its desethyl analog.

The data shown in Table I suggest that the inhibitory effect of oxygenated sterols is highly dependent on the configuration of the epoxide or the hydroxyl on the side chain : (24S)-24,25-epoxycholesterol was a much more potent inhibitor than the 24R-isomer, and (22S)-22-hydroxycholesterol is less potent than the 22R-isomer. It is intriguing to note that the configurational effect of the 22-hydroxyl group was also observed in the interaction with dipalmitoylphosphatidyl choline in liposome, and in the ADP-induced platelet aggregation. The remarkable inhibitory effect of (24S)-24,25-epoxycholesterol, a natural product of mammalian steroid biosynthesis by rat liver enzyme, suggests that this compound is a biological regulator of steroid synthesis.

The present experiment clearly indicates that HMG-CoA reductase is not the sole target enzyme of sterol synthesis inhibition by oxygenated sterols, but lanosterol demethylation and/or the subsequent transformation ultimately leading to cholesterol are also affected by these compounds. It may be considered that cholesterol synthesis in organisms is controlled by oxygenated sterols not only at the stage of HMG-CoA reductase but also after formation of the steroid nucleus. The inhibitory effects are strictly related to the chemical structures of the oxygenated sterols. A more systematic study may provide greater insight into the relation between the chemical structure and the inhibitory effect. 